\title{
Experimental Organism Fibro-osseous Lesion
}

National Cancer Institute

\section{Source}

National Cancer Institute. Experimental Organism Fibro-osseous Lesion. NCI Thesaurus.

Code C139146.

Accumulation of a mixed cell population of non-neoplastic mesenchymal cells along endosteal surfaces which may be associated with focal osteoclastic bone resorption and marrow fibroplasia. (INHAND) 